Helgoländer wiss. Meeresunters. 17, 335-339 (1968)

\title{
Hydrocarbon pollution of the sea and its influence on marine organisms
}

\author{
Oleg G. Mironov \\ Institute of Biology of the South Seas, A.S. Ukr. SSR Sevastopol, USSR
}

KURZFASSUNG: Verunreinigung des Meeres durch Kohlenwasserstoffe und ihr Einfluß auf marine Organismen. Hinsichtlich der Verunreinigung des Meeres durdh Kohlenwasserstoffe stellt die Verschmutzung durch $O 1$ und Olprodukte ein höchst aktuelles Problem dar. Von den ins Meer entlassenen Olprodukten werden in erster Linie die Oberflächenschichten und ihre Lebensgemeinschaften (Hyponeuston), aber auch die in tieferen Zonen lebenden Organismen betroffen, vor allem das Phyto- und Zooplankton. Versuche an 20 verschiedenen Planktonalgen zeigten, daß Olprodukte stark toxisch wirken und diese töten oder ihre Vermehrung hemmen. Frei bewegliche Tiere, wie Fische, vermögen günstigenfalls aus ölverschmutzten Meeresgebieten abzuwandern. Organismen des Benthos werden durch Olverschmutzungen ebenfalls, doch offensichtlich nicht in so starkem Maße, geschädigt. Es wird darauf hingewiesen, daß noch unzureichende Kenntnisse über die Folgen einer kurz- bzw. langfristigen Einwirkung von Olprodukten auf Meeresorganismen bestehen.

\section{INTRODUCTION}

Pollution of the seas, especially during the last years, is acquiring an everincreasing scale. At present the various wastes appearing in sea-water have been registered not only in the coastal zone but also in offshore waters, even in the central regions of seas and oceans. It is not accidental, therefore, that the question of seawater pollution has often been discussed at different international and national conferences and is the subject of discussion at this jubilee symposium of the "Biologische Anstalt Helgoland".

Most acute is the problem of sea pollution by hydrocarbons, particularly, oil and oil products. There is reason to assume a further increase of oil pollution owing to (1) the expansion of the marine fleet, including the tanker fleet, ships with 150 to 200 thousand tons displacement; (2) the use of the shelf zone for additional oil sources (from a total area of continental slope of about 27.5 million $\mathrm{km}^{2}, 8$ to 10 million $\mathrm{km}^{2}$ may harbour oil reserves); (3) poor efficacy of legislative measures to prevent oil pollution (present legislation does not totally exclude discharge of oil into the sea, but limits it only to the 30 to 70 mile zone).

The different aspects of oil pollution in the sea have been studied in a number of countries, however, the efforts made in this direction are insufficient. The present report is concerned only with the biological consequences of this problem considering 
the influence of hydrocarbon pollution on marine organisms; we shall not touch the other important side of oil pollution namely, the role of marine organisms in the process of cleansing sea-water from hydrocarbons.

\section{BIOLOGICAL CONSEQUENCES OF HYDROCARBON POLLUTION}

Upon entering the sea-water, oil firstly influences the marine organisms which inhabit the surface layers of the sea. This surface layer $(0$ to $5 \mathrm{~cm})$ carries a peculiar marine community, the hyponeuston, in which many mass species among the pelagic and bottom animals develop during their early stages, including those that have a great value in commercial fishery (Zartsev 1961). The development of fecundated spawn of the plaice (Rbombus maeoticus) which - according to our experiments - showed extreme sensitivity to the influence of oil products present in sea-water, may serve as an example. In this case the injury in spawn was noted at concentrations of $10^{-4}$ to $10^{-5} \mathrm{ml} / \mathrm{l}$. In these concentrations of oil products, 40 to $100 \%$ of the hatched pre-larvae showed some signs of degenerations during development and perished.

Penetrating from the surface into the deeper water layers, hydrocarbons may influence also other organisms. It is probable that floating organisms - particularly phytoand zooplankton - which, unlike fish, are unable to avoid active contact with oil pollution products, are especially exposed to injury. GaLTsoff and others (cit. in ZoBelL 1964) indicate that concentrations of oil products in ports, lagoons and bottom sediments of harbours badly affect diatoms and other species of microscopic algae. We conducted experiments (Mironov \& LansKaya 1966) on 20 species of planktonic algae from the Black, Red, and Mediterranean Seas as well as from the Atlantic Ocean; our studies showed that various oils and oil products exhibit a definite toxic effect on these algae resulting in death or a retardation in cell division. Moreover, the sensitivity of different species to concentrations of oil products in sea-water varies significantly, sometimes up to several orders of magnitude. The toxic effects of oil products on planktonic algae taken from the different seas illustrate some general features of hydrocarbon influence on marine phytoplankton.

Experiments dealing with the influence of oil and oil products on zooplankton organisms are poorly eluciadated in literature, however, available observations in natural conditions indicate the ability of some zooplankton organisms to accumulate hydrocarbons (products of insufficient fuel combustion). According to data by MALLET \& SARDou (1964) and Mallet \& Lami (1965), plankton consisting mainly of Podon, other Cladocera and some Copepoda, was noted to contain benzo-3-4-pyren in concentrations up to $40 \gamma$ per $100 \mathrm{~g}$. It seems appropriate, therefore, to expect that for the life processes of the planktonic organisms, hydrocarbon accumulation is not a matter of indifference. Our observations showed that Acartia perishes during the first 24 hours at a concentration of $0.1 \mathrm{ml} / 1$ oil in sea-water, and after 72 to 96 hours at a concentration 10 times less. A similar situation exists in regard to Calanus.

Most nectonic organisms, particularly fish, can escape the contact with oil pollution by avoiding polluted areas. Such behaviour may sometimes affect their 
migrational pattern. An example of fishes avoiding oil contaminated regions is the wreckage of the tanker "Timako Maru" (NoRTH 1961). Toxicity of meat as well as increased fish lethality was noted in several cases after contact with oil. This brought significant losses to the fisheries industries owing to a decrease in catch as well as to the reduced quality of fish meat.

Some data indicate that benthic organisms, molluscs for example, are not affected by oil polluted sea-water. According to ORTON (1925), oil has little effect on young Patella. According to data by GeORge (1961), molluscs are not affected by oil pollution and oil products leave no toxic effects even after passing through the gastrointestinal tract of these organisms. ZoBell (1964), referring to MACKIN (1950), indicates a greater resistance in oysters to oil pollution. However, observations in natural and artificial habitats of oysters showed a significant decrease in their quantity reaching to complete disappearance from polluted sea-water, particularly when polluted with "black oil". This has already been noted by GRAFFe (1903) and Zernov (1934). We believe that some of this controversy can be explained by the fact that on the one hand experiments or observations were carried out under natural conditions on adult forms during a comparatively short period of time, and on the other, the disappearance of the organisms in their habitats were observed during a prolonged period in gradually detriorating quality of sea-water affecting pre-larval stages which are known to be more sensitive to unfavourable environmental conditions. Our experiments carried out with adult and pre-larval stages of Balanus sp. showed the latter to be a hundred times more sensitive to oil pollution than the adult forms.

During the last years, the attention of scientists was drawn to dolphins that can, evidently, in the future help man to disclose the mysteries, and utilize the riches, of the ocean. It may be assumed that these animals, having a well developed central nervous system and cortex, are very sensitive to sea-water polluted with oil products which appear to effect the dolphins on their conditioned-reflex activity.

Oil pollution is a great calamity for the sea birds. In Great Britain, for instance, from 50 to 250 thousand sea birds annually perish as a result of oil pollution (TENDron 1962). Besides direct poisening during the act of swallowing, oil products touching the bird deprive it of the means of flying as well as dissolve the grease on its feathers which in its turn results in super-cooling and finally death (see also the article by GOETHE in this volume).

The observations on oil pollution available are sufficient to document their unfavourable influence on the marine flora and fauna. However, extremely few studies have been conducted yet in this important field and a number of sections concerning this problem are only beginning to develop.

Thus, little is known about the biological consequences of prolonged exposure to low concentrations of oil products on marine organisms, a situation often encountered under natural conditions. On the other hand there are some studies available on shortterm influences of various hydrocarbon concentrations, including large doses, on marine hydrobionts. Such situations too often occur under natural conditions owing to the great mobility of oil products; as a result of this marine organisms - after comparatively short contact with polluted sea-water (hours, minutes) - may find themselves in clear sea-water again. Experiments on marine microscopic algae showed that 
many species lost their viability after having been in sea-water polluted with oil products for a short period of time. There are no data on long-term after-effects of hydrocarbon intoxication, in particular in regard to such important biological criteria as are reproduction, fecundity and viability of offspring of marine hydrobionts.

Due to the effect of several factors, hydrocarbons, including oil and oil products may take a complex route in the oceans - from the surface to the bottom and back again - thus influencing all groups of marine organisms in the various water layers and at the sea bottom. They may affect microscopic marine organisms, fishes, mammals and birds. This gives us enough reason to speak of the appearance of a new, unfavourable, ecological factor in the sea, the growing intensity of which may lead to permanent changes in the biological structure of seas and oceans which in the end may significantly undermine their productivity.

\section{SUMMARY}

1. Marine oil pollution is becoming a major problem. The amount of pollution by oil and oil products may be expected to increase in the near future due to (a) the increase in number of sea going ships, including the tanker fleet, (b) the use of shelf zones for oil drilling, (c) poor international legislative measures to prevent oil pollution in the open seas.

2. Hydrocarbon products, especially oils, exert detrimental effects on the hyponeuston (organismic community near the water surface), eggs and larvae of fishes, e. g., the plaice (Rbombus mateoticus) phyto- and zooplankton, nectonic organisms, including adult fishes (via direct damage or by causing them to emigrate), and a variety of benthic organisms.

3. In general, eggs and larval stages of marine organisms seem to be more sensitive than their adult counterparts.

4. There is great need for long-term studies employing sublethal criteria.

5. Marine birds are killed by the thousand and hundred-thousands per year due to oil pollution.

6. Hydrocarbon pollution represents a new, unfavorable, ecological factor which may lead to permanent changes in the biological structure of the oceans and coastal waters, and which finally may reduce their productivity.

\section{LITERATURE CITED}

George, M., 1961. Oil pollution of marine organisms. Nature, Lond. 192 (4808), 1209.

GraefFE, E., 1903. Übersicht der Seethierfauna des Golfes von Triest nebst Notizen über Vorkommen, Lebensweise, Erscheinungs- und Fortpflanzungszeit der einzelnen Arten. Arb. zool. Inst. Univ. Wien $3(3), 333-344$.

Mallet, L. \& Sardou, L., 1964. Recherche de la présence de l'hydrocarbure polybenzénique benzo-3.4 pyrène dans le milieu planctonique de la région de la baie de Villefranche (Alpes-Maritimes). C. r. bebd. Séanc. Acad. Sci., Paris 258 (21), 5264-5267.

- \& LAMI, R., 1965. Recherche sur la pollution du plancton par les hydrocarbures polybenzéniques du type benzo-3-4-pyrène dans l'estuaire de la Rance. C. r. Séanc. Soc. Biol. $158,2261-2262$. 
Mironov, O. G. \& LansKajA, L. A., 1966. The influence of oil on the development of marine phytoplankton. Int. oceanogr. Congr. 2 (Moscow).

NorTH, W. J., 1961. Successive biological changes observed in a marine cove exposed to large oil spillage. Ref. Ser. Inst. mar. Resour. Univ. Calif, 61-6.

TENDRON, G., 1962. La pollution des mers par les hydrocarbures et la contamination de la flore et de la faune marines. Revue gén. Sci. pur. appl. 69, 9-10.

Zarrsev, J. P., 1961. Surface pelagic biocenosis of the Black Sea. [Russ.] Zool. Zh. 40 (6).

Zernov, S. A., 1934. Obščaja gidrobiologija (General hydrobiology). [Russ.] Gosudarstv. Izd. Biologičeskoj i Medicinskoj Lit., Moskva, 503 pp.

ZoBELL, C., 1964. The occurrence, effects and fate of oil pollution in the sea. In: Advances in water pollution research. Proceedings of the International Conference held in London, Sept. 1962. Vol. 3. Ed. by E. A. Pearson. Pergamon Press, Oxford, 85. [Repr.]

\section{Discussion (by correspondence) following the paper by Mironov}

KINNE: I have listened to your paper with great interest and would like to ask a number of questions. First of all, you have quoted Russian studies concerning the extreme sensitivity of early developmental stages of Rhombus maeoticus to oil products. Can you give us more information about the kind of oil products tested? Would you care to comment on the immediate physiological causes of the detrimental effects observed? Which signs of degeneration did hatched pre-larvae show; were they primarily structural or functional in nature?

Mironov: In our experiments we used crude oil, diesel oil and mazout. The main type of degeneration was the distortion of the body of Rhombus maeoticus larvae. The mechanism of the oil product's effect was not studied. You will find details concerning this problem in my article published in Voprosy icbtiologii 7, 577 (1967).

KINNE: In regard to the 20 species of planktonic algae studied by yourself and LANSKAYA you made the important statement that the sensitivity to oil products may vary up to several orders of magnitude. Which were the most sensitive species? Do you think they could serve as biological indicators providing fast and reliable information on the actual danger to marine life?

Mironov: The greatest sensitivity to oil pollution in our experiments showed Ditylum brightwellii (WEST) GRÜN. The use of some microscopic algae, in particular planktonic forms (MIRONov 1961), as indicators of sea water pollution seems possible. However, this problem demands special investigation.

KINNE: Can you give us examples of cases in which nectonic organisms, especially fishes, escaped oil polluted sea areas by emigration? The results reported by NoRTH (1961) appear to be related to a marine cove rather than to the open sea.

Mrronov: We have not conducted special experiments in this field. However from changes in fish catches from coastal areas, we can make suppositions, to a certain extent, about fish migrations under the effect of oil pollution.

Kinne: Your statement that dolphins (presumably especially of the genus Delpbinus) may help in the future to detect polluted water areas, seems of great practical interest. Have experiments been conducted yet on this problem, and if so, what behavioral reactions of the dolphins have been used as criteria? Do you not think that continuous use of dolphins as "pollution receptors", progressive "domestication", and maintenance in nearshore waters or aquaria, may ultimately result in some degree of conditioning to water affected by man-produced substances and hence reduce their ability to sense differences in water quality?

Mironov: We may assume that these animals, possessing a well-developed central nervous system and cortex, are very sensitive to sea water polluted by oil products; the latter appear to effect the dolphins' conditioned-reflex activity. 